\title{
The S-Adenosyl-L-Homocysteine Hydrolase Gene ahcY of Agrobacterium radiobacter K84 Is Required for Optimal Growth, Antibiotic Production, and Biocontrol of Crown Gall Disease
}

\author{
Ramón Penyalver, ${ }^{1,2}$ Phil M. Oger, ${ }^{1}$ Shengchang Su, ${ }^{1}$ Belén Alvarez, ${ }^{2}$ Carmina I. Salcedo, ${ }^{2}$ \\ María M. López, ${ }^{2}$ and Stephen K. Farrand ${ }^{1}$ \\ ${ }^{1}$ Department of Microbiology, University of Illinois at Urbana-Champaign, Urbana, IL 61801, U.S.A.; ${ }^{2}$ Centro de Protección \\ Vegetal y Biotecnología. Instituto Valenciano de Investigaciones Agrarias (IVIA), Apartado Oficial, Moncada 46113, \\ Valencia, Spain
}

Submitted 20 November 2009. Accepted 25 February 2009.

Agrobacterium radiobacter $\mathrm{K84}$ is a commercial agent used worldwide to control crown gall disease caused by pathogenic isolates of $A$. tumefaciens. More than 2,000 transposon insertion derivatives of strain $\mathrm{K84}$ were screened by a standardized greenhouse bioassay to identify mutants defective in biocontrol. Three mutants affected in biocontrol properties were identified. All three mutants displayed normal levels of attachment to tomato seed and root colonization. One of these mutants, M19-164, exhibited partial biocontrol and did not produce detectable levels of agrocin 84. In this mutant, the transposon is located in the agn locus of pAgK84, which codes for agrocin 84 biosynthesis. The second mutant, M19-158, also exhibited partial biocontrol and produced reduced amounts of agrocin 84 as a result of a mutation in a chromosomal gene of unknown function. The third mutant, M9-22, failed to biocontrol, was impaired in both growth in minimal medium and siderophore production, and failed to produce detectable levels of agrocin 84. The chromosomal gene $a h c Y$, which encodes $S$ adenosyl-L-homocysteine hydrolase, was disrupted in this mutant. Expression of a functional copy of ahcY in M9-22 restored all of the altered phenotypes. The fact that all identified biocontrol mutants exhibited a partial or total defect in production of agrocin 84 indicates that this antibiotic is required for optimum biocontrol. This study also identified two chromosomally encoded genes required for agrocin 84 production. That a mutation in ahcY abolishes biocontrol suggests that the intracellular ratio of $S$ adenosyl-L-methionine to $S$-adenosyl-L-homocysteine is an important factor for agrocin 84 biosynthesis. Finally, we

Current address of P. Oger: Laboratoire de Sciences de la Terre, Université de Lyon, UMR CNRS 5570, Ecole Normale Supérieure de Lyon, 46 allée d'Italie, Lyon, F-69334, France.

Current address of S. Su: Department of Molecular Genetics, Biochemistry and Microbiology, University of Cincinnati, College of Medicine, Cincinnati, OH 45267, U.S.A.

Corresponding author: R. Penyalver; Telephone: (34) 96342 4000; Fax: (34) 96342 4001; E-mail: penalver_ram@gva.es

Nucleotide sequence data is available in the GenBank database under accession number AY178804.

* The $e$-Xtra logo stands for "electronic extra" and indicates a supplemental figure is published online. demonstrate that the ahcY gene in strain $\mathrm{K84}$ is also required for optimal growth as well as for antibiotic production and biocontrol of crown gall disease.

Crown gall disease, caused by tumorigenic strains of Agrobacterium spp., can be efficiently prevented by one of the few commercially available biological control agents, Agrobacterium radiobacter K84 (Kerr 1972; Moore and Canfield 1996; New and Kerr 1972) or its improved form, strain K1026 (Jones and Kerr 1989; Jones et al. 1988; Penyalver et al. 2000). Therefore, studies on strain K84 can offer important clues to understanding factors contributing to successful and commercially useful disease suppression by $A$. radiobacter as well as other potential biocontrol agents. Production of a highly specific antiagrobacterial antibiotic called agrocin 84, the synthesis of which is encoded by pAgK84 (Farrand et al. 1985), is a major component of biocontrol by strain K84 (Kerr and Htay 1974). The complete sequence of pAgK84 predicts synthesis and mode of action of agrocin 84, which targets leucyl-tRNA synthetase (Kim et al. 2006; Reader et al. 2005). However, the antibiotic is active only against a subset of pathogenic strains of A. tumefaciens that are able to take up the antibiotic (Hayman and Farrand 1988; Kerr and Htay 1974; Murphy and Roberts 1979). Agrocin 84 is required for the efficient control of crown gall caused by agrocin 84-sensitive strains of $A$. tumefaciens; mutants of strain K84 that do not produce this antibiotic weakly control galling by such pathogens (Cooksey and Moore 1982; Johnson and DiLeone 1999; Kerr and Htay 1974; López et al. 1989). However, strain K84 also can control, albeit less effectively, pathogens that are resistant to agrocin 84 under field conditions (Bouzar et al. 1991; Cooksey and Moore 1980; López et al. 1987, 1989; Penyalver and López 1999; Penyalver et al. 2000; Vicedo et al. 1993). Thus, if agrocin 84 synthesis is an essential component of biocontrol in strain $\mathrm{K} 84$, it alone is not sufficient to explain the biocontrol properties of this bacterium (Farrand and Wang 1992).

In addition to agrocin 84, strain $\mathrm{K} 84$ produces at least two other antiagrobacterial substances: agrocin 434 (Donner et al. 1993) and the antibiotic-like substance 84 (ALS84) (Peñalver et al. 1994). Agrocin 434 is effective only against biovar 2 Agrobacterium pathogens, and several lines of evidence show that this antibiotic is required, but not sufficient, to protect plants from infection by agrocin 434-sensitive isolates (McClure et 
al. 1998). In addition, agrocin 434 production is not involved in the control of agrocin 434-resistant strains and, therefore, cannot explain the ability of agrocin 84-deficient mutants of strain K84 to control agrocin 84-resistant pathogens in the field (López et al. 1989). ALS84, an hydroxamate-type siderophore is produced by strain K84 when grown under low iron conditions (Penyalver et al. 2001). Nothing is known about the involvement of this or other siderophores in the biocontrol of crown gall. Additional traits such as blockage of infection sites through wound colonization and biofilm formation (AbarcaGrau et al. 2006; Cooksey and Moore 1982; Ellis et al. 1979; Lippincott and Lippincott 1969), competitive root colonization (Penyalver and López 1999; Shim et al. 1987), and iron competition (Penyalver et al. 2001) also may contribute to successful biocontrol by strain K84 (Farrand and Wang 1992; Johnson and DiLeone 1999; López et al. 1989; Penyalver and López 1999). However, to date, there is no experimental evidence to support the involvement of any of these traits in the ability of strain K84 to control crown gall disease.

In this study, we have developed and tested a quantitative greenhouse assay for screening large numbers of mutants of strain K84 for those defective in biocontrol properties. An initial screen yielded three mutants, two with insertions in novel chromosomal genes required for wild-type levels of production of agrocin 84 in strain K84. One of these genes, ahcY, codes for $S$-adenosyl-L-homocysteine hydrolase, and it is required for optimal growth in minimal medium as well as antibiotic production and control of crown gall disease.

\section{RESULTS}

Bioassay design.

We tested four commercial tomato hybrids using A. tumefaciens C58 to identify a cultivar that is highly and uniformly susceptible to the pathogen. In all, 60 to 100 seedlings, all 1 month old, of hybrids 'Sunglobe', 'Brigade', 'Sunbeam', and
'Sunny' were root inoculated by dipping into a bacterial suspension of the pathogen at $5 \times 10^{8} \mathrm{CFU} / \mathrm{ml}$ for one $\mathrm{min}$ as described below. $\mathrm{Cv}$. Sunny was selected for its uniform susceptibility to crown gall as assessed by the percentage of galled plants and weight of tumors (data not shown). Once we settled on this cultivar, we determined the lowest inoculation levels of pathogen required to produce $>90 \%$ probability of forming at least one gall on each root system under our inoculation and plant-growth conditions. Then, 25 to 50 seedlings were root inoculated by dipping plants for 1 min into suspensions of strain $\mathrm{C} 58$ at population densities ranging from approximately $10^{4}$ to $10^{8} \mathrm{CFU} / \mathrm{ml}$. Percentages of galled plants over different plant incubation periods are shown in Figure 1. The lowest pathogen titer required to produce galls in at least $90 \%$ of the plants after growing the plants for 5 weeks was $10^{7}$ $\mathrm{CFU} / \mathrm{ml}$. Under these conditions, all diseased plants presented more than 15 tumors per root system.

We next determined at what population density strain K84 would prevent galling at the lowest pathogen inoculation level. Replicates of root-pruned tomato seedlings were pretreated at two different concentrations of strain K84, $10^{8}$ and $10^{9} \mathrm{CFU} / \mathrm{ml}$, for $1 \mathrm{~min}$. Each root system was then inoculated by dipping into a suspension of strain C58 for $1 \mathrm{~min}$. Two titers were used: that required to produce $>90 \%$ probability of galling $\left(10^{7} \mathrm{CFU} / \mathrm{ml}\right)$ and one decade higher $\left(10^{8}\right.$ $\mathrm{CFU} / \mathrm{ml}$ ). We observed a reduction in the disease incidence, as assessed by the percentage of galled plants, and also in the severity of the disease; all diseased plants treated with strain K84 presented a lower number of galls than untreated plants under all treatment conditions tested (Table 1). A suspension of $10^{9} \mathrm{CFU} / \mathrm{ml}$ of strain $\mathrm{K} 84$ in the initial inoculum was required to prevent all galling produced by the pathogen at a challenge population density of $10^{7} \mathrm{CFU} / \mathrm{ml}$. Subsequently, all biocontrol assays were performed using populations of biocontrol agent and challenging pathogen of $10^{9}$ and $10^{7}$ $\mathrm{CFU} / \mathrm{ml}$, respectively.

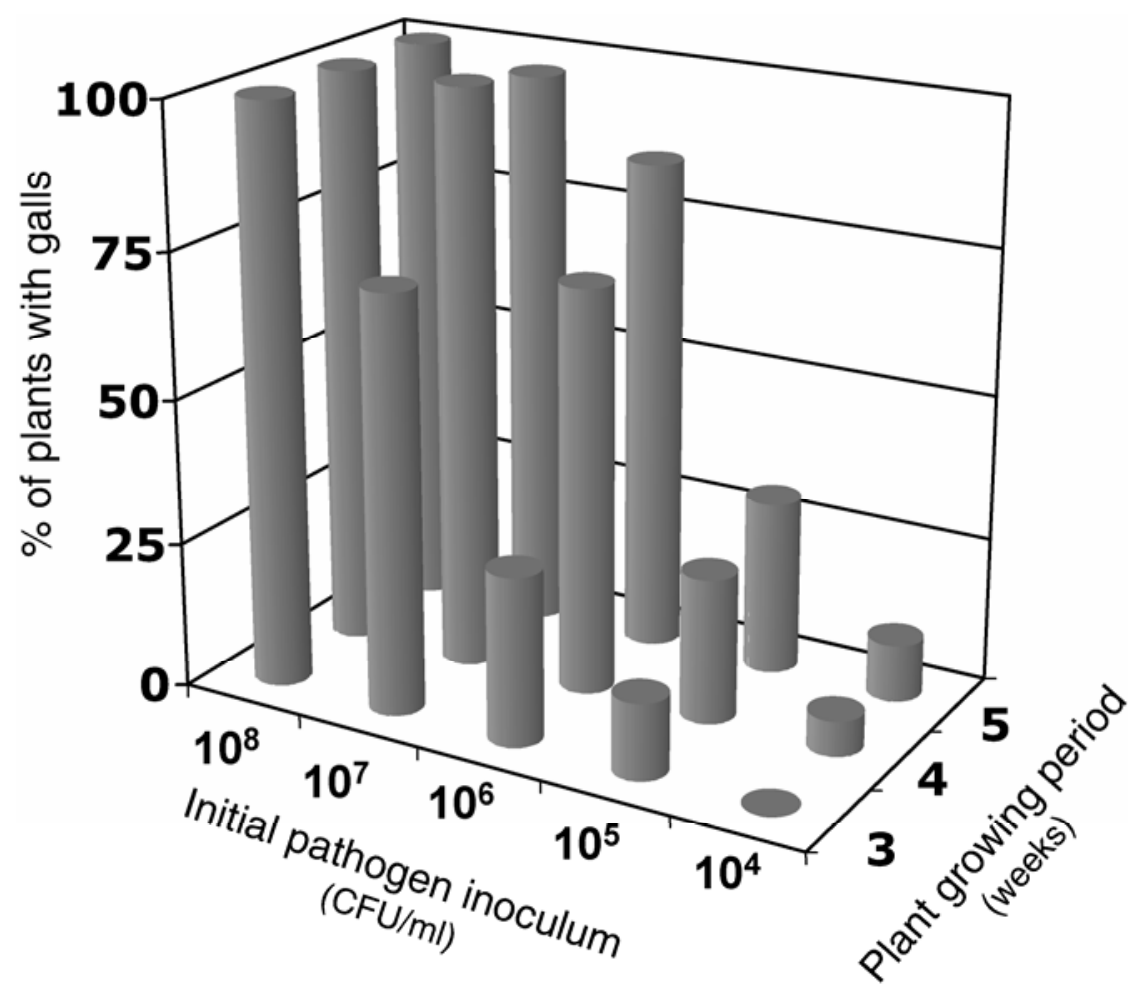

Fig. 1. Optimization of the infection assay. In total, 25 to 503 -week-old tomato seedlings of cv. Sunny were wounded at the crown with an inoculating needle and root pruned just before inoculation. Plants were then dipped for 1 min into a suspension of strain C58 at population densities ranging from approximately $10^{4}$ to $10^{8} \mathrm{CFU} / \mathrm{ml}$. The lowest pathogen titer required to produce galls in at least $90 \%$ of the plants after growing the plants for 5 weeks was $10^{7} \mathrm{CFU} / \mathrm{ml}$. 


\section{Isolation of biocontrol mutants of strain K84.}

We tested more than 2,000 transposon-induced mutants of strain K84 for biocontrol using the standardized conditions described above. The initial one-plant screen yielded three mutant-treated plants showing higher numbers of galls than plants treated with wild-type K84. The loss of biocontrol efficiency was confirmed for the three potential mutants in our second, quantitative 10-plant assay (Table 2). Two of the three mutants, M19-158 and M19-164, were partially defective in biocontrol. For these two mutants, approximately $60 \%$ of the treated plants showed galls but the number of galls per plant was drastically reduced from more than 20 galls in the untreated K84 controls to between 1 and 6 galls in the treated plants. The

Table 1. Efficient biocontrol depends on population size of strain K84

\begin{tabular}{lccc}
\hline $\begin{array}{l}\text { Titer, } \\
\text { treatment }\end{array}$ & $\begin{array}{c}\text { No. of galled } \\
\text { plants }\end{array}$ & $\begin{array}{c}\text { Plants with } \\
\text { galls }(\%)\end{array}$ & $\begin{array}{c}\text { No. of tumors per } \\
\text { diseased plant }\end{array}$ \\
\hline $10^{7}$ & & & \\
Untreated & $10 / 10$ & 100 & $>30$ \\
$10^{8}$ & $9 / 17$ & 53 & $1-10$ \\
$10^{9}$ & $0 / 17$ & 0 & 0 \\
$10^{8}$ & & & \\
Untreated & $10 / 10$ & 100 & $>50$ \\
$10^{8}$ & $8 / 9$ & 88 & $5-20$ \\
$10^{9}$ & $4 / 9$ & 44 & $1-5$ \\
\hline
\end{tabular}

a Pathogen titer used and biocontrol treatment. Two pathogen titers were used for tumor induction: that required to produce $>90 \%$ of galled plants $\left(10^{7} \mathrm{CFU} / \mathrm{ml}\right)$ and one decade higher $\left(10^{8} \mathrm{CFU} / \mathrm{ml}\right)$. Plants were pretreated at two different concentrations of strain $\mathrm{K} 84,10^{8}$ and $10^{9} \mathrm{CFU} / \mathrm{ml}$, or were treated with buffer (untreated).

Table 2. Three mutants of strain K84 are defective in controlling crown gall

\begin{tabular}{lccc}
\hline $\begin{array}{l}\text { Biocontrol } \\
\text { treatment }\end{array}$ & $\begin{array}{c}\text { No. of } \\
\text { galled plants }\end{array}$ & $\begin{array}{c}\text { Index of } \\
\text { biocontrol }(\%)^{\text {a }}\end{array}$ & $\begin{array}{c}\text { No of tumors per } \\
\text { diseased plant }\end{array}$ \\
\hline Untreated & $10 / 10$ & 0 & $10-25$ \\
K84 & $0 / 10$ & 100 & 0 \\
M9-22 & $10 / 10$ & 0 & $>20$ \\
M19-158 & $6 / 10$ & 40 & $1-3$ \\
M19-164 & $6 / 10$ & 40 & $2-6$ \\
\hline
\end{tabular}

${ }^{\mathrm{a}}$ Index of biocontrol $=[1-($ number of galled plants in treatment/number of galled plants in control)] $\times 100$ (Penyalver and López 1999).

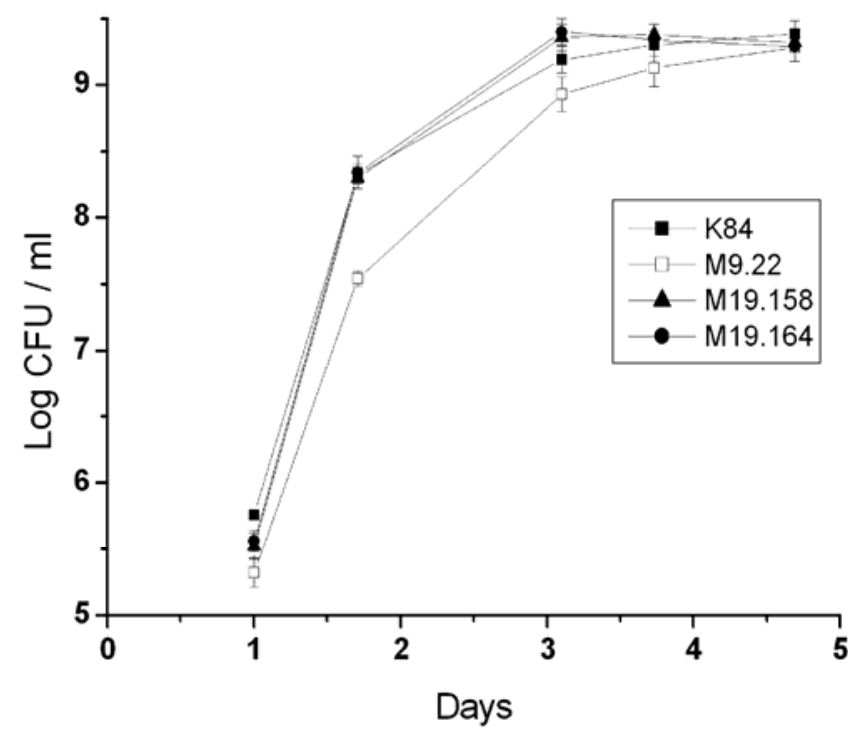

Fig. 2. Growth of strain K84 and its biocontrol defective mutants in ABM liquid medium (Chilton et al. 1974). Cell growth, expressed as CFU per milliliter, was monitored by viable counts at the indicated times (days). Bars represent the standard deviation of data from two independent experiments. third mutant, M9-22, failed completely to protect plants from galling. The number of galled plants as well as the severity of the disease was indistinguishable from plants treated only with the pathogen, making this isolate the sole mutant completely impaired in biocontrol identified in the screening (Table 2).

\section{Growth characteristics of the biocontrol mutants.}

All three biocontrol-defective mutants grew at wild-type rates and reached the same final yields as the wild-type parent when grown in a rich medium, MG/L (Cangelosi et al. 1992) (data not shown). However, when grown in ABM minimal medium (AB minimal medium (Chilton et al. 1974) supplemented with mannitol), mutant M9-22 grew more slowly than strain K84, al-
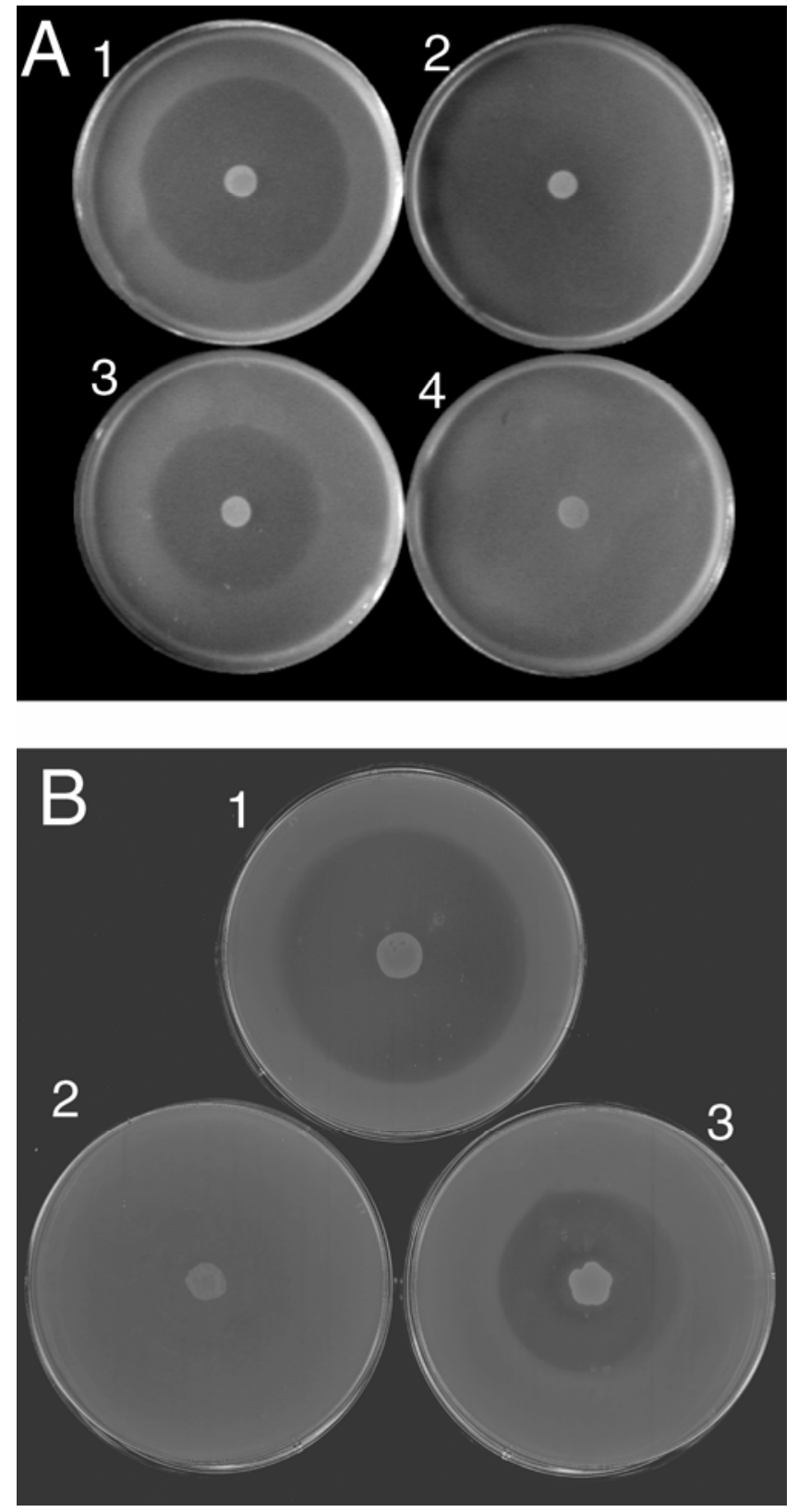

Fig. 3. Agrocin 84 production by the wild-type strain K84 and its biocontrol defective mutants. A, Stonier's medium plates (Stonier 1956) were spot inoculated with 1, wild-type strain K84; 2, mutant M9-22; 3, mutant M19-158; and 4, mutant M19-164. B, Plates were spot inoculated with 1, wild-type strain K84; 2, mutant M9-22; and 3, mutant M19-22(pAhcY). Plates were grown for 3 days. Production of agrocin 84 was assessed by overlaying the plates with a suspension of the agrocin 84-sensitive strain C58 (Peñalver et al. 1994). 
though it reached the same final population yield in stationary phase (Fig. 2). The growth of the other two biocontrol-defective mutants, M19-158 and M19-164, in ABM minimal medium was indistinguishable from that of wild-type K84 (Fig. 2).

\section{Biocontrol-deficient mutants are affected}

in agrocin 84 or ALS84 biosynthesis.

Mutants M9-22 and M19-164 did not produce detectable amounts of agrocin 84 (Fig. 3A). Mutant M19-158 produced less agrocin 84 than strain K84 as assessed by the diameter of the zone of inhibition of the indicator.

Mutants M19-158 and M19-164 produced wild-type amounts of ALS84 as measured by the diameter of the zones of inhibition in our standard assay, while mutant M9-22 produced lesser amounts of the siderophore as previously reported (Penyalver et al. 2001) (Table 3).

\section{Biocontrol-deficient mutants are not affected} in attachment to tomato seed or in root colonization.

All three mutants attached to tomato seed at population densities similar to that of wild-type strain $\mathrm{K} 84\left(10^{3}\right.$ to $10^{4}$ CFU/seed) (Fig. 4A). All three mutants colonized the roots of germinated seedlings at densities similar to strain K84, yielding approximately $10^{5}$ to $10^{6} \mathrm{CFU} /$ root segment at 15 and 28 days after seed inoculation (Fig. 4B).

\section{Genetic analyses of the biocontrol mutants.}

Mutant M9-22 was isolated following Tn5 mutagenesis and mutants M19-158 and M19-164 were obtained by $\mathrm{Tn} V$ mutagenesis (Table 4). Southern analysis, using probes specific for the relevant element, established that each mutant contains a single copy of the transposon, with the element being located on 8.2-, approximately 14-, and approximately 23-kb EcoRI fragments for mutants M9-22, M19-158, and M19-164, respectively (data not shown). These three transposon-bearing EcoRI fragments were cloned from the respective mutants to generate pPOM9-22, pRCM19-158, and pRCM19-164 (Table 4).

Complete sequencing of the EcoRI fragment containing the M9-22 insertion from pPOM9-22 revealed a 2,398-bp segment of K84 DNA containing two partial open reading frames (ORF) (Fig. 5A). The amino acid sequence of the translated product from the first ORF into which the transposon is inserted in the M9-22 mutant shows extensive homology to the translated products of $a h c Y$ from many bacteria. This gene codes for $S$-adenosyl-L-homocysteine hydrolase. The $a h c Y$ allele of strain K84 is located on chromosome 1 (gene ID Arad0039) and is 1,401 bp long, and the transposon is inserted between nucleotides 864 and 865 . The amino acid sequence of AhcY from strain K84 shows the highest similarity with orthologs from Rhizobium etli (95\% identities [I] and 97\% similarity [S]), R. leguminosarum (95\% I and 97\% S), Sinorhizobium meliloti $(90 \%$ I and $94 \%$ S), S. medicae (90\% I and $94 \%$ S), and A. tumefaciens C58 (87\% I and $94 \% \mathrm{~S})$. Based on the amino acid sequence analysis, the second ORF could encode a putative two-component sensor histidine kinase (gene ID Arad0038). The neighborhood of genes in which $a h c Y$ is located in strain K84 is highly syntenic within the family Rhizobiaceae (Capela et al. 2001, Galibert et al. 2001; González et al. 2006; Goodner et al. 2001; Kaneko et al. 2000; Wood et al. 2001; Young et al. 2006) (data not shown).

The transposon insertion in mutant M19-158 is located in gene $\operatorname{arad} 3704$ of chromosome 1, which has been annotated in the K84 genome as a conserved hypothetical protein of un known function (Fig. 5B). This gene could code for a product
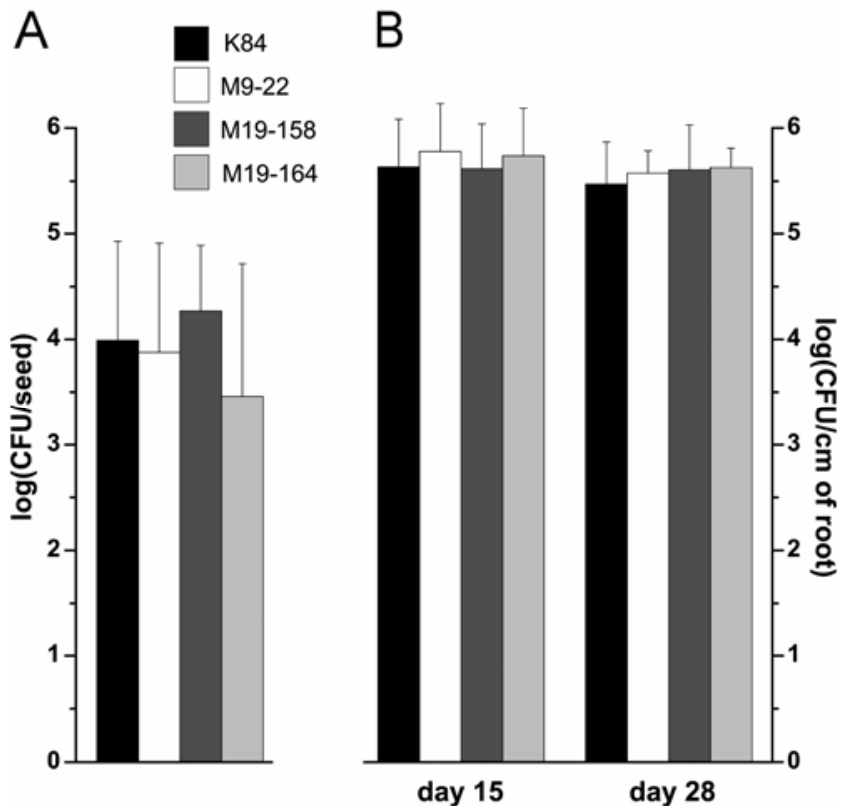

Fig. 4. Biocontrol defective mutants are not affected in either $\mathbf{A}$, tomato seed attachment or $\mathbf{B}$, further root tip colonization. Each bar represents the mean value of two independent experiments with four replicate plants each $(n=8)$ No significant difference for any of the treatments $(P=0.3388,0.8589$, and 0.7869 for seed colonization and root colonization day 15 and 28 , respectively).

Table 3. Summary of the properties of the biocontrol-defective mutants of strain K84

\begin{tabular}{|c|c|c|c|c|c|c|c|c|c|c|}
\hline Strain & $\begin{array}{c}\text { Defect } \\
(\%)^{\mathrm{a}}\end{array}$ & $\begin{array}{c}\text { Growth in } \\
\text { MG/L }\end{array}$ & $\begin{array}{c}\text { Growth in } \\
\text { ABM }^{\mathbf{b}}\end{array}$ & $\begin{array}{c}\text { Agrocin } \\
84^{c}\end{array}$ & ALS84 $^{d}$ & Seed $^{\mathrm{e}}$ & $\begin{array}{c}\text { Root } \\
\text { tip }^{\mathrm{e}}\end{array}$ & Insertion $^{\mathrm{f}, \mathrm{g}}$ & $\begin{array}{c}\text { Disrupted } \\
\text { gene }^{\mathrm{g}}\end{array}$ & Gene function \\
\hline K84 & 0 & + & + & $+(5.4)$ & $+(2.0)$ & + & + & & & \\
\hline M9-22 & 100 & + & SL & $-(<0.01)$ & $\pm(0.4)$ & + & + & Chromosome 1 & $a h c Y$ & $\begin{array}{l}\text { Recycle of } S \text {-adenosyl-L- } \\
\text { homocysteine }\end{array}$ \\
\hline M19-158 & 60 & + & + & $\pm(4.5)$ & $+(2.0)$ & + & + & Chromosome 1 & Arad3704 & Possible metalloprotein \\
\hline M19-164 & 60 & + & + & $-(<0.01)$ & $+(2.0)$ & + & + & pAgK84 & agn locus & Agrocin 84 production \\
\hline
\end{tabular}

${ }^{a}$ Degree of biocontrol defect.

${ }^{\mathrm{b}}$ Rates of exponential growth in rich MG/L (Cangelosi et al. 1992) and minimal ABM (AB [Chilton et al. 1974] supplemented with mannitol) liquid media were determined; + indicates a growth rate similar to that of the wild-type strain K84; SL = slightly slower.

${ }^{c}$ Measured on Stonier's medium as the diameter of the zones of inhibition of C58, in centimeters, caused by the indicated producer strain after growing for 3 days on the antibiosis plate assay. Differences are presented as relative sizes of inhibition zones.

${ }^{\mathrm{d}}$ Production of ALS84 measured on MG medium as the diameter of the zones of inhibition, in centimeters, of NT1 caused by the indicated producer strain after growing for 2 days on the antibiosis plate assay. Differences are presented as relative sizes of inhibition zones (Penyalver et al. 2001).

e Attachment to tomato seed (Seed) and further root tip colonization (Root tip) of germinated seedlings were evaluated for the mutants and the wild-type in a gnotobiotic system; + indicates a seed attachment and root population densities similar to that of the wild-type strain K84.

${ }^{\mathrm{f}}$ Location of the insertion element.

${ }^{\mathrm{g}}$ Replicons and gene identification numbers follow the nomenclature provided by the Genome Sequencing of Agrobacterium Biovar Type Strains for A. radiobacter $\mathrm{K} 84$ at Virginia Tech. 
Table 4. Bacterial strains and plasmids used

\begin{tabular}{|c|c|c|}
\hline Strains or plasmid & Relevant genotype, phenotype, or characteristic ${ }^{a}$ & Reference or source \\
\hline \multicolumn{3}{|l|}{ Strains } \\
\hline \multicolumn{3}{|l|}{ Escherichia coli } \\
\hline DH5 $\alpha$ & supE44 $\Delta l a c U 169$ (Ф80lacZAM15) hsdR17 recA1 endA1 gyrA96 thi-1 relA1 & Sambrook et al. 1989 \\
\hline S17-1 & Pro $^{-}$Res $^{-}$Mod $^{+}$recA; integrated RP4-Tet::Mu-Kan::Tn7, Mob $^{+} \mathrm{Tp}^{\mathrm{r}}$ & Simon et al. 1983 \\
\hline $1830(\mathrm{pJB} 4 J \mathrm{~J})$ & met-63 pro- 22 nal $\mathrm{Km}^{\mathrm{r}} ; \mathrm{Tn} 5$ delivery strain & Beringer et al. 1978 \\
\hline $\mathrm{S} 17-1(\mathrm{pPOX})$ & $\begin{array}{l}\text { Pro }^{-} \text {Res }^{-} \text {Mod }^{+} \text {recA; integrated RP4-Tet::Mu-Kan::Tn7, } \text { Mob }^{+} \mathrm{Tp}^{\mathrm{r}}, \mathrm{Km}^{\mathrm{r}} ; \mathrm{Tn} V(\mathrm{Tn} 5-\text { OriV}) \\
\text { delivery strain }\end{array}$ & This study \\
\hline \multicolumn{3}{|c|}{ Agrobacterium tumefaciens } \\
\hline C58 & Tumorigenic strain; Agrocin 84-susceptible pathogen & Our collection \\
\hline NT1 & Ti plasmid-less C58 derivative; Agrocin 84-resistant; ALS84-susceptible & Our collection \\
\hline \multicolumn{3}{|l|}{ A. radiobacter } \\
\hline K84 & Wild-type biocontrol strain; $\mathrm{Agr}^{+}$ & Kerr 1972 \\
\hline M9-22 & Tn5-induced mutant of K84; defective in biocontrol; $\mathrm{Agr}^{-}$ & This study \\
\hline M19-158 & $\mathrm{Tn} V$-induced mutant of K84; defective in biocontrol; $\mathrm{Agr}^{+}$ & This study \\
\hline M19-164 & $\mathrm{Tn} V$-induced mutant of $\mathrm{K} 84$; defective in biocontrol; $\mathrm{Agr}^{-}$ & This study \\
\hline \multicolumn{3}{|c|}{ 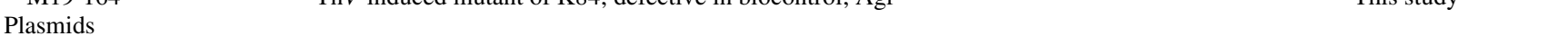 } \\
\hline pUC19 & ColE1-based cloning vector, $\mathrm{Ap}^{\mathrm{r}}$ & Sambrook et al. 1989 \\
\hline pBluescript SK+ & ColE1-based cloning vector, $\mathrm{Ap}^{\mathrm{r}}$ & Sambrook et al. 1989 \\
\hline PQKK & IncP1-based cloning vector, $\mathrm{Tc}^{\mathrm{r}}$ & Quin et al. 2004 \\
\hline pSUP5011 & Vector containing $m o b$ functions & Simon 1984 \\
\hline pTF1 & Suicide vector containing $\operatorname{Tn} V(\operatorname{Tn} 5$-ori $V)$ transposon & Furuichi et al. 1985 \\
\hline pPOX & BamH1 fragment (mob functions) from pSUP5011 cloned into pTF1 & This study \\
\hline pPOM9-22 & 8.2-kb EcoRI fragment containing the Tn 5 insertion from M9- 22 cloned in pUC19 & This study \\
\hline pRCM19-158 & $\approx 14-\mathrm{k}$ b $E c o$ RI fragment containing the $\mathrm{Tn} V$ insertion from M19-158 ligated on itself & This study \\
\hline pRCM19-164 & $\approx 23-\mathrm{k}$ b EcoRI fragment containing the Tn $V$ insertion from M19-164 ligated on itself & This study \\
\hline pAhcY & $\begin{array}{l}\text { 1,588-bp polymerase chain reaction fragment containing the ahcY open reading frame (1,401 bp) } \\
\text { cloned into pOKK that complements the } 9-22 \text { mutation }\end{array}$ & This studv \\
\hline
\end{tabular}

${ }^{a}$ Abbreviations: $\mathrm{Mob}^{+}$, mobilizes transfer of other plasmids; $\mathrm{Agr}^{+}$, produces agrocin 84; $\mathrm{Agr}^{ \pm}$, produces smaller amounts of agrocin 84 than strain K84; $\mathrm{Agr}^{-}$, does not produce detectable amounts of agrocin $84 ; \mathrm{Km}^{\mathrm{r}}, \mathrm{Ap}^{\mathrm{r}}$, and $\mathrm{Tp}^{\mathrm{r}}$ indicates resistance to kanamycin, ampicillin, and trimethoprim, respectively.

\section{A ahcYlocus}

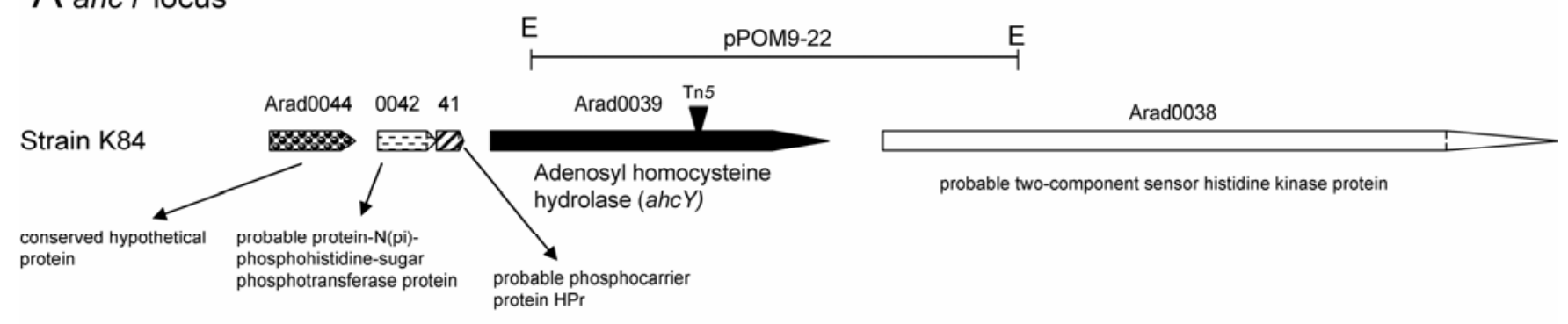

B arad3704 locus

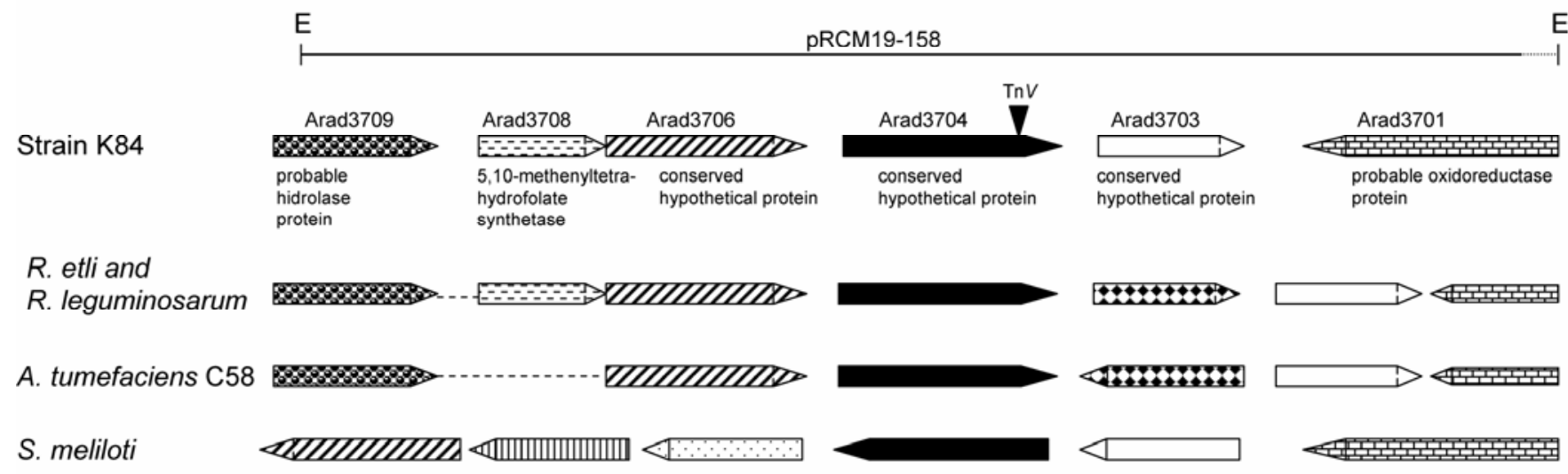

$\approx 1 \mathrm{~Kb}$

Fig. 5. Genetic structure of the $a h c Y$ and $\operatorname{arad} 3704$ loci. A, The 2,398-bp EcoRI fragment from pPOM9-22 into which the Tn5 is inserted in mutant M9-22 is indicated by a line above the genetic map. The position of the Tn5 insertion is indicated by a black triangle. B, The 8.4-kb EcoRI fragment from pRCM19158 into which the $\operatorname{Tn} V$ is inserted in mutant M19-158 is indicated by a line above the genetic map. The position of the $\operatorname{Tn} V$ insertion is indicated by a black triangle. Shown below the locus of strain K84 are the homologous regions from the four closest orthologous of arad3704 from Rhizobium etli, R. leguminosarum, Agrobacterium tumefaciens C58, and Sinorhizobium meliloti. In all cases, orthologous genes from different species are indicated by identical fill patterns. 
belonging to the metallo-hydrolase/oxidoreductase superfamily. The amino acid sequence translated from this gene shows high levels of similarity with orthologs from $R$. etli $(68 \%$ I and $81 \%$ S), A. tumefaciens (67\% I and $79 \%$ S), R. leguminosarum (65\% I and $78 \%$ S), S. medicae (58\% I and $73 \%$ S), and S. meliloti (57\% I and $71 \% \mathrm{~S}$ ). The synteny of the $\operatorname{arad} 3704$ gene locus is conserved among the Rhizobium/Agrobacterium cluster of strains but not in the closely related S. meliloti species (Capela et al. 2001, Galibert et al. 2001; González et al. 2006; Goodner et al. 2001; Kaneko et al. 2000; Wood et al. 2001; Young et al. 2006) (Fig. 5B).

Table 5. The $a h c Y$ gene of strain $\mathrm{K} 84$ restores biocontrol ability to mutant M9-22

\begin{tabular}{lccc}
\hline $\begin{array}{l}\text { Biocontrol } \\
\text { treatment }^{\text {a }}\end{array}$ & $\begin{array}{c}\text { No. of galled } \\
\text { plants }\end{array}$ & $\begin{array}{c}\text { Index of } \\
\text { biocontrol }(\boldsymbol{\%})^{\mathbf{b}}\end{array}$ & $\begin{array}{c}\text { No. of tumors per } \\
\text { diseased plant }^{\mathbf{c}}\end{array}$ \\
\hline None & $20 / 20$ & 0 & $2.2 \pm 0.8$ \\
K84 & $0 / 20$ & 100 & 0 \\
M9-22 & $18 / 20$ & 10 & $1.7 \pm 0.8$ \\
M9-22(pAhcY) & $1 / 20$ & 95 & $1 \pm 0$ \\
\hline
\end{tabular}

${ }^{\text {a }}$ Root-pruned tomato seedlings of cv. Roma were pretreated with the biocontrol strain K84 or with each mutant at a population density of $10^{9}$ $\mathrm{CFU} / \mathrm{ml}$ and subsequently inoculated with the challenge pathogen strain C58 by dipping the dried root systems into a bacterial suspension of $10^{7}$ $\mathrm{CFU} / \mathrm{ml}$ for $1 \mathrm{~min}$. Untreated control plants were pretreated with buffer and subsequently inoculated with the pathogen.

${ }^{\mathrm{b}}$ Index of biocontrol $=[1-($ number of galled plants in treatment/number of galled plants in control)] × 100 (Penyalver and López 1999).

${ }^{c}$ Mean and standard deviations of the number of tumors per galled plants are shown.
Our restriction enzyme analysis of pAgK84 plasmids from biocontrol mutants clearly showed that the $\operatorname{tn} V$ insertion in mutant M19-164 is located within EcoRI fragment A of pAgK84 (data not shown), the plasmid that codes for biosynthesis of agrocin 84 (Wang et al. 1994). More specifically, fragment A contains the agnA, agnB1B2, and agnC1C2C3 genes (Kim et al. 2006), all of which are essential for production of agrocin 84 (Ryder et al. 1987).

\section{The $a h c Y$ gene is required}

\section{for wild-type antibiotic production and biocontrol.}

The ahcY ORF as well as the upstream intergenic region were amplified by polymerase chain reaction (PCR), cloned into pQKK to give pAhcY (Table 4), and introduced into M922 by conjugation to give strain M9-22(pAhcY). The cloned ahcY gene restored almost completely growth in minimal medium (Supplementary Fig. S1) as well as the production of ALS84 (data not shown). The complemented mutant also produced near-wild-type levels of agrocin 84 (Fig. 3B). In addition, the cloned ahcY gene fully restored the biocontrol capabilities to the mutant (Table 5; Fig. 6). These results confirm that $a h c \mathrm{Y}$ gene is sufficient to complement in trans the pleiotrophic phenotype of strain M9-22.

\section{Effect of metabolites on growth rate and agrocin 84 production in the $a h c Y^{-}$mutant $\mathrm{M9-22}$.}

Given that $S$-adenosyl-L-homocysteine hydrolase plays important roles in the regeneration of $S$-adenosyl-L-methionine (AdoMet) and that methionine (Met) feeds into the cycle (Fig. 7), we assessed the ability of these two metabolites to restore

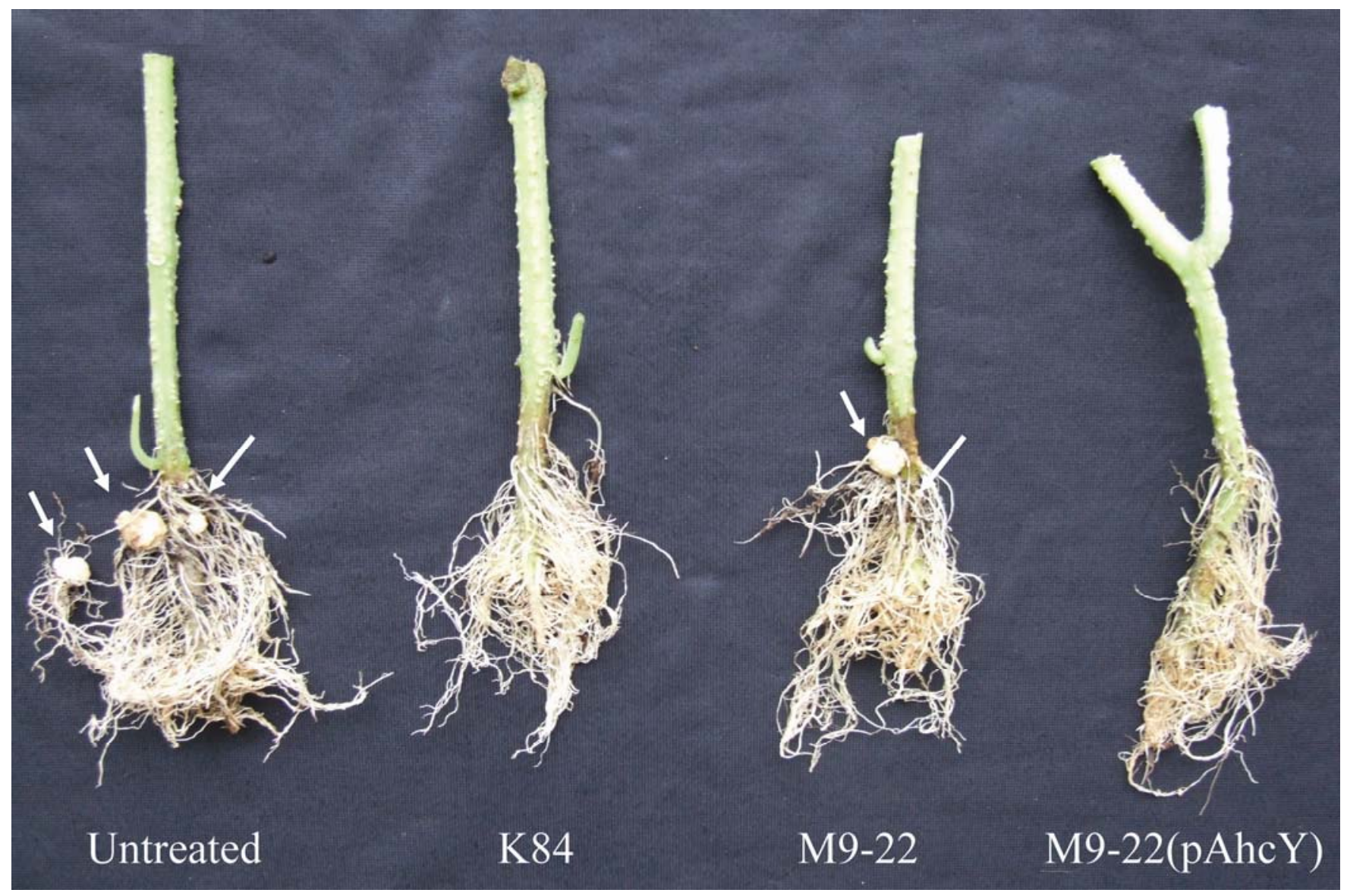

Fig. 6. ahcY gene of strain $\mathrm{K} 84$ restores biocontrol ability to mutant M9-22. Root-pruned tomato seedlings of cv. Roma were pretreated with buffer (untreated control) or with a bacterial suspension of strain K84, the ahcY mutant M9-22, and the complemented mutant M9-22(pAhcY) at a population density of $10^{9} \mathrm{CFU} / \mathrm{ml}$ for $5 \mathrm{~min}$ and subsequently inoculated with the challenge pathogen by dipping the root systems into a bacterial suspension of $10^{7}$ $\mathrm{CFU} / \mathrm{ml}$ of strain C58 for $1 \mathrm{~min}$. White arrows indicate galls in the diseased plants. 
production of agrocin 84 in mutant M9-22. Growth of the mutant was restored to wild-type levels in minimal medium supplemented with AdoMet or with Met (Table 6). However, production of agrocin 84 was not restored in this mutant by adding AdoMet (Table 6). Adding Met to the medium allowed mutant M9-22 to produce detectable amounts of agrocin 84 but at levels clearly lower compared with wild-type production (Fig. 8). Neither metabolite had any effect on the amount of agrocin 84 produced by the complemented mutant M9-22(pAhcY) (Fig. 8).

\section{DISCUSSION}

In the present study, we describe the development of a quantitative, high-throughput biocontrol assay that can be applied to the screening of large numbers of mutants of strain K84 under conditions that mimic the control of crown gall disease in the field by this widely successful biocontrol agent. The basis for this bioassay, which follows closely horticultural practices, relies on the careful optimization of the populations of the biocontrol agent and the challenge pathogen, and gives a reproducible $100 \%$ level of infection in the absence of the biocontrol agent and $100 \%$ control when strain K84 is introduced. Thus, any perturbation in biocontrol abilities in the mutants should lead to galling on the plants. In total, three out of more than 2,000 mutants tested showed a reduced biocontrol efficiency ranging from 60 to $100 \%$ loss of biocontrol activity compared with the parent strain. All three mutants were defective to varying degrees in the production of agrocin 84 . The observation that strain M19-164, which does not produce any agrocin 84 , is not completely defective in controlling the challenge pathogen confirms that our bioassay reproduces biocontrol conditions in the field (López et al. 1989). Furthermore, the observation that the three mutants isolated in our test are compromised to different extents in the synthesis of agrocin 84 confirms the importance of this antibiotic in the control of agrocin 84 -sensitive pathogens by strain K84. Our inability to isolate a biocontrol mutant that produces wild-type levels of agrocin 84 can be explained by the relatively small number of mutants tested in the present study. Clearly, we have not saturated the genome; whereas approximately $20 \mathrm{~kb}$ of pAgK84 is required for synthesis of agrocin 84 (Farrand et al. 1985; Kim et al. 2006), we isolated only one mutant with an insertion in the agn region of this plasmid. However, in our bioassay, agro- cin 84 production accounts for approximately $60 \%$ of the biocontrol efficiency. Thus, it remains possible that the presence of agrocin 84 may mask the effect of other mutations and reduce the sensitivity of our bioassay. The two-step procedure using a single plant as a prescreen may also exclude mutations that do not affect agrocin 84 synthesis. However, the fact that mutant M19-158 isolated in this study produces close to wildtype amounts of agrocin 84, regardless of the drawbacks mentioned above, indicates that the basis of the design is sound. Several improvements to this design can be proposed for further analysis of this or other biocontrol systems using this approach. First, one might increase the number of plants in the prescreen to improve sensitivity. Second, one might mutagenize a stable, unmarked antibiotic-deficient mutant in place of the antibiotic-producing wild-type strain. Thus, production of antibiotics could not mask the effect of other mutations. Third, including an agrocin84-resistant strain as a challenge pathogen should yield biocontrol mutants of strain K84 that still produce the antibiotic.

Table 6. Effect of metabolites on growth rate and production of agrocin 84 in the $a h c Y^{-}$mutant $\mathrm{M} 9-22$

\begin{tabular}{l}
\hline \\
\cline { 2 - 2 } Treatment
\end{tabular}

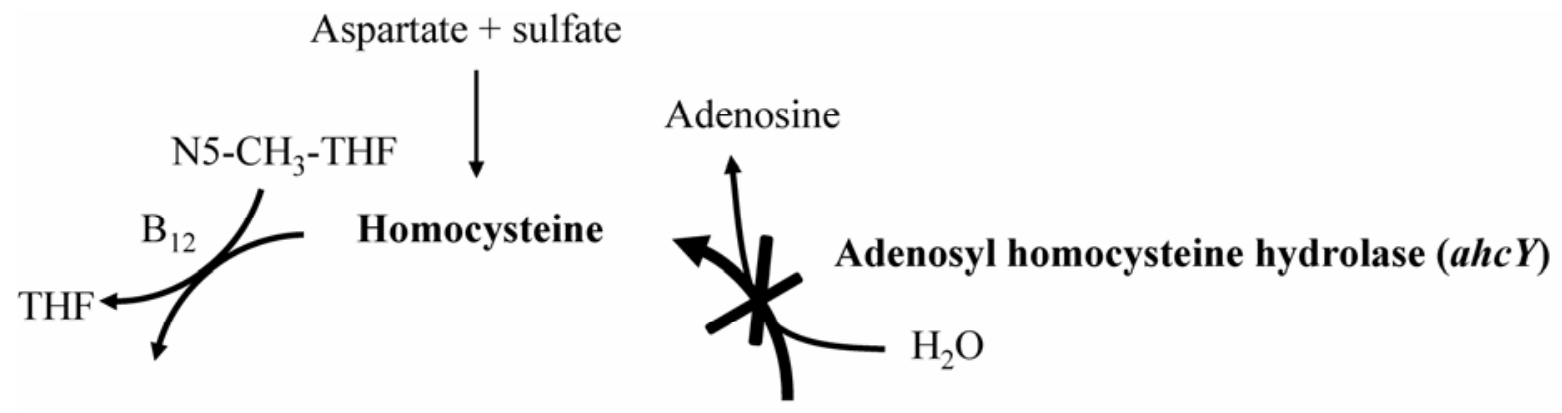

Methionine

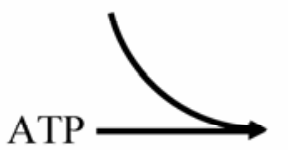

$S$-Adenosyl Homocysteine (AdoHcy)

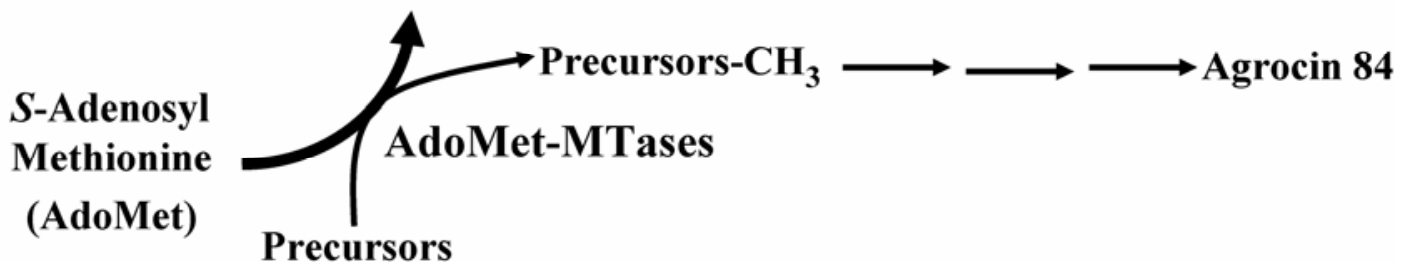

Fig. 7. Role of AhcyY in S-adenosyl-L-homocysteine recycling. The methylation of precursors of agrocin 84 biosynthesis is shown as an example of AdoMetdependent methyl transfer reactions. AdoMet-MTases, AdoMet-dependent methyl transferases. Adapted from Sganga and associates (1992). 
Our results confirm the central role of agrocin 84 in biocontrol by strain $\mathrm{K} 84$, because all three mutants showed a reduced production of this antibiotic. One of the three mutants bears an insertion in the agrocin 84-coding region of pAgK84. The transposon insertions in the two other mutants are located in two physically distant loci on chromosome 1 . One of these two genes, ahcY, encodes $S$-adenosyl-L-homocysteine hydrolase (AdoHyase) (Fig. 7), which catalyzes the hydrolysis of $S$-adenosyl-L-homocysteine (AdoHcy) to adenosine and homocysteine. AdoHcy is formed as a direct product of methyltransferase reactions involving $S$-adenosyl-L-methionine (AdoMet) as the methyl donor. Several genes encoding putative SAM-dependent methyl transferases are required for biosynthesis of agrocin 84 (Kim et al. 2006). Because AhcY is required for recycling AdoHcy to AdoMet, we suggest that the failure to recycle AdoHcy leads to an intracellular accumulation of this compound (Sganga et al. 1992), which is a natural noncompetitive inhibitor of AdoMet-mediated methyl transfer reactions (Cantoni et al. 1979). In addition, the mutation could result in failure to produce pool sizes of AdoMet sufficient for the synthesis of agrocin 84. Normal growth of the $a h c Y$ mutant was also restored in minimal medium supplemented with AdoMet $(1 \mathrm{mM})$ and Met $(100 \mathrm{mM})$ or in a complex medium, thereby indicating that the hydrolysis of $S$-adenosyl-L-homocysteine (AdoHcy) plays a key role in the metabolism of sulfur-containing amino acids, as has been reported for other bacteria (Sganga et al. 1992). Adding AdoMet to the solid culture medium did not restore production of agrocin 84 under the conditions tested. However, adding high amounts of Met partially restored production of agrocin 84 , suggesting that an alteration in the ratio of AdoMet to AdoHcy may be responsible for the block in synthesis of agrocin 84 .

The ahcY mutant also produces lesser amounts of the hydroxamate siderophore ALS84 compared with its parent. In a previous study, we identified arad8230 as an essential gene for ALS84 synthesis (Penyalver et al. 2001). This gene is located on chromosome 2 of strain K84 and is orthologous to $v b s S$, which codes for a nonribosomal peptide synthase involved in the biosynthesis of the hydroxamate siderophore vicibactin in $R$. leguminosarum (Carter et al. 2002). Two lines of evidence suggest that the effect of the mutation in the ahcY gene on ALS84 synthesis is indirect. First, no SAM-dependent methyltransferases are required for the synthesis of vicibactin (Carter et al. 2002). Second, whereas agrocin 84 synthesis is totally blocked, ALS84 is only partially reduced in mutant M9-22. Thus, we propose that the reduced production of siderophore by the mutant results from a more generalized cellular dysfunction, which also leads to its altered growth phenotype.

When provided in trans, the $a h c \mathrm{Y}$ gene was able to complement the mutation in M9-22, confirming the role of the SAM cycle for the synthesis of agrocin 84. This complementation did not restore any of the phenotypes observed in the mutant to wild-type levels. We expressed the $a h c Y$ gene as a clone in a moderate copy number vector. Thus, because of copy number, it is not likely that the gene was expressed at its normal physiological levels. In addition, although the $a h c Y$ upstream (and likely regulatory) sequence is present on that clone, it is likely that the regulation loop of that cycle cannot regulate the expression of the cloned ahcY gene to wild-type levels. Either overexpression (most likely) or underexpression (less likely) could easily result in the observed phenotype. The need for a tight control of each gene and catabolite in the SAM cycle is further confirmed by the partial complementation observed when providing two of the cycle intermediates, methionine or AdoMet, exogenously to the mutant M9-22. However, the key point here is that we see near-normal production of the antibiotic in the complemented mutant, and that this results in wildtype levels of biocontrol by the M9-22(pAhcY) strain.

The three mutants M9-22, M19-158, and M19-164 showed different degrees of the defect in biocontrol and production of agrocin 84 or ALS84 (Table 5). Only M9-22 is totally deficient in biocontrol. In addition to the failure in agrocin 84 produc-

\section{K84}

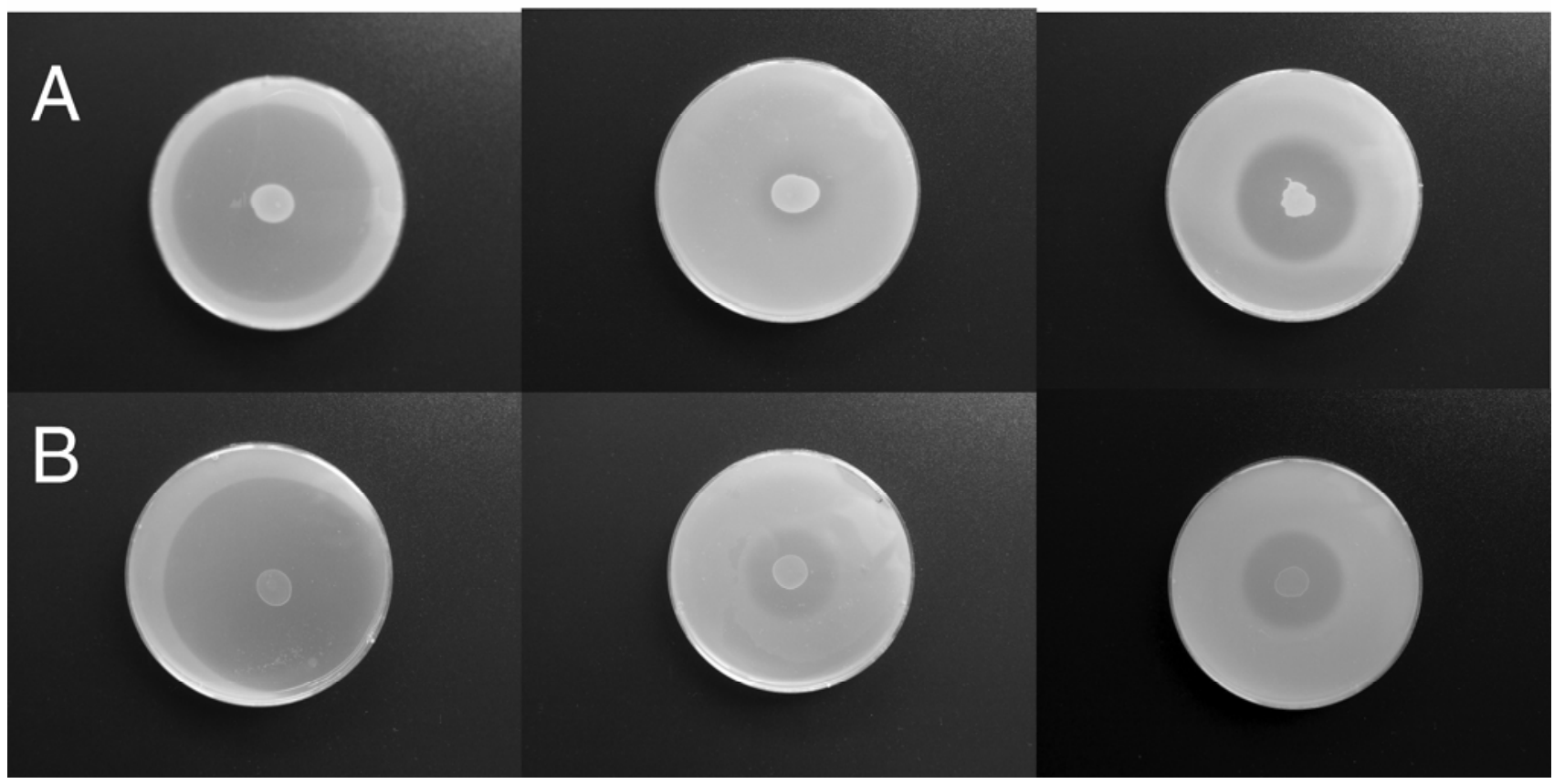

Fig. 8. Methionine partially restores production of agrocin 84 to the ahcY mutant. A. Stonier's medium (Stonier 1956) plates and B, those containing methionine (100 mM) were spot inoculated with wild-type strain K84, the $a h c Y^{-}$mutant M9-22, and the complemented mutant M19-22(pAhcY). Producer strains were grown for 3 days. Production of agrocin 84 was assessed by overlaying the plates with a suspension of the agrocin 84 -sensitive indicator strain $\mathrm{C} 58$ and incubating for $48 \mathrm{~h}$ at $28^{\circ} \mathrm{C}$ (Peñalver et al. 1994). 
tion, this mutant produces lesser amounts of ALS84. The mutant also is slightly impaired in its growth in minimal medium, although this does not impair its ability to colonize tomato roots. These observations suggest a possible role for ALS84 in biocontrol as proposed by Penyalver and associates (2001).

M19-158 produces near wild-type levels of agrocin 84 but exhibits a great defect in biocontrol similar to that of mutant M19-164, which does not produce detectable levels of the antibiotic (Table 3). The insertion in M19-158 is located in arad3704, which codes for a putative $\mathrm{Zn}$-dependent hydrolase of the lactamase B superfamily. The variety of activities observed in this family makes extrapolating the link between the mutation in arad3704 and biocontrol elusive, especially in the absence of a strong phenotype in addition to the reduction in biocontrol efficiency. One of those activities might be related to quorum-quenching lactonase, which degrades acyl-homoserine lactone signals (Dong and Zhang 2005; Uroz et al. 2009). Many of those enzymes are members of the $\mathrm{Zn}$-dependent hydrolase family of metalloproteins (Thomas et al. 2005; Uroz et al. 2009). The possible role of quorum-quenching in biocontrol of crown gall by strain K84 will be further investigated.

\section{MATERIALS AND METHODS}

\section{Bacterial strains, plasmids, and media.}

Bacterial strains and plasmids used in this study are listed in Table 4. Luria broth (Gibco-BRL, Gaithersburg, MD, U.S.A.) was used for Escherichia coli. Agrobacterium strains were grown on MG/L agar (Cangelosi et al. 1992) and in AB minimal medium (Chilton et al. 1974) supplemented with mannitol $(0.2 \%$; ABM) as the carbon source. ABM was further supplemented with biotin $(2 \mu \mathrm{g} / \mathrm{ml})$ for strain $\mathrm{K} 84$ and its mutants. Antibiotics were used at the following concentrations: for Agrobacterium, kanamycin $(\mathrm{Km})$ at $100 \mu \mathrm{g} / \mathrm{ml}$, neomycin $(\mathrm{Nm})$ at $100 \mu \mathrm{g} / \mathrm{ml}$, gentamicin $(\mathrm{Gm})$ at $100 \mu \mathrm{g} / \mathrm{ml}$, and tetracycline (Tc) at $2 \mu \mathrm{g} / \mathrm{ml}$; and for E. coli, $\mathrm{Km}$ at $50 \mu \mathrm{g} / \mathrm{ml}$ and $\mathrm{Tc}$ at $20 \mu \mathrm{g} / \mathrm{ml}$. Tumorigenic A. tumefaciens C58, a nopaline/ agrocinopine-type strain that is susceptible to agrocin 84 (Engler et al. 1975), was used as the challenge pathogen.

\section{DNA manipulations.}

Plasmid DNA was isolated from Agrobacterium spp. and $E$. coli by the alkaline lysis procedure as previously described (Hayman and Farrand 1990). Total genomic DNA was prepared according to the protocol of Glickmann and associates (1998). Standard recombinant DNA techniques were used as described by Sambrook and associates (1989). Plasmids were introduced into $E$. coli strains by transformation using $\mathrm{CaCl}_{2}$ or electroporation, and into Agrobacterium spp. by electroporation or biparental cross-streak mating using E. coli S17-1 harboring the plasmid of interest as the conjugative donor (Farrand et al. 1996; Simon et al. 1983).

\section{Transposon mutagenesis \\ of strain $\mathrm{K84}$ and insertion rescue.}

$\mathrm{Tn} 5$, which codes for resistance to $\mathrm{Km}$ and $\mathrm{Nm}$, was introduced into strain K84 via the suicide plasmid pJB4JI by conjugation with E. coli 1830 (Beringer et al. 1978) as previously described (Farrand et al. 1985; Penyalver et al. 2001). TnV (Tn5OriV) was introduced into strain K84 via the suicide plasmid pPOX by conjugation with $E$. coli $\mathrm{S} 17-1$. pPOX was constructed in this study by cloning the BamH1 fragment harboring the oriT and mob functions from pSUP5011 (Simon 1984) into pTF1 containing Tn5-OriV (TnV) (Furuichi et al. 1985). Transposoninduced mutants of K84 were selected on ABM supplemented with $\mathrm{Km}$ and $\mathrm{Nm}$ (each at $100 \mu \mathrm{g} / \mathrm{ml}$ ) and analyzed for biocontrol abilities by the bioassay developed as described below. Tn 5 insertions were rescued by ligating EcoRI-digested genomic DNA purified from transposon-induced mutants into pUC19 or pBluescript SK+ and selecting for resistance to kanamycin. For $\mathrm{Tn} V$ rescue, genomic DNA purified from mutants was digested with EcoRI and self-ligated, and recombinant clones were recovered as described for $\mathrm{Tn} 5$ rescue.

\section{Southern analysis.}

Genomic DNA samples were digested with EcoRI, and the fragments were separated by electrophoresis on $0.7 \%$ agarose gels and transferred to a nylon membrane (Boehringer Mannheim GmbH, Mannheim, Germany) as described by Sambrook and associates (1989). Southern hybridizations were performed using the 5.4-kb internal HindIII fragment of Tn5 labeled by random priming with digoxigenin-dUTP as a probe. Prehybridization, hybridization, and colorimetric detection were performed using the DNA High Prime Labeling and Detection kit (Boehringer Mannheim $\mathrm{GmbH}$ ) as recommended by the manufacturer.

\section{DNA sequence analysis.}

Nucleotide sequences were determined with an ABI PRISM DNA sequencer 377 (Perkin-Elmer, Norwalk, CT, U.S.A.) at the facilities of the Institute for Molecular and Cellular Plant Biology, Valencia, Spain. Regions of K84 DNA flanking the transposon were sequenced from the mutated fragments after subcloning HindIII fragments between transposon and vector in pBluescript $\mathrm{SK}+$. The complete sequences of both strands were determined for the mutated fragment from mutant M9-22 and transposon-flanking regions from mutant M19-158 by primer walking from the transposon using the primers $5^{\prime}$-AAG GTTCCGTTCAGGACGCTAC-3' and PF-3 (Chuang et al. 1999 ) and from the vector using polylinker primers. Sequences were aligned with the CLUSTAL W 1.8 program and analyzed using the similarity search tool BLAST program. Nucleotide sequences of the 2,398-bp mutated fragment from mutant M922 containing a segment of the $a h c Y$ gene and partial sequence of a two-component sensor histidine kinase homologue were deposited in the GenBank database under accession number AY178804.

\section{ahcY gene cloning.}

A fragment of $1,588 \mathrm{bp}$ containing the $a h c Y$ gene was obtained by PCR amplification of genomic DNA from strain K84 using the forward 5'-AACTGCAGCGCCCGCCGCTCC GCTC-3' and reverse 5'-CCCAAGCTTTCAGTATCTGTAGT GGTC-3' primer set and cloned between the PstI and HindIII sites of the broad-host-range vector pQKK (Qin et al. 2004). This fragment contains the $a h c Y$ ORF $(1,401 \mathrm{bp})$ and the entire promoter region of the gene.

\section{Preparation of inocula.}

Agrobacterium strains were cultured for 2 days at $26^{\circ} \mathrm{C}$ on MG/L agar medium. Mid-exponential-phase cells were scraped from the surface of the agar and suspended in $0.4 \mathrm{M}$ phosphate buffer $(\mathrm{pH} 7.2)$ to densities of approximately $5 \times$ $10^{8} \mathrm{CFU} / \mathrm{ml}$ (optical density at $560 \mathrm{~nm}\left[\mathrm{OD}_{560}\right]=0.5$ ) for the pathogen or approximately $10^{9} \mathrm{CFU} / \mathrm{ml}\left(\mathrm{OD}_{560}=0.8\right)$ for the biocontrol agent or its mutants. These initial population densities were verified in each experiment by spreading decade dilutions of the suspensions on MG/L plates. Suspensions of pathogen and biocontrol agent ranging from $10^{4}$ to $10^{9}$ were made by decade-diluting initial suspensions in phosphate buffer.

\section{Biocontrol assay.}

Three-week-old tomato seedlings of cv. Sunny were root pruned and wounded at the crown with an inoculating needle 
just before inoculation. Plants were then dipped for 1 min into a suspension of the biocontrol agent and left to dry on a sterile paper towel for $15 \mathrm{~min}$ before being dipped into a suspension of the challenging pathogen. After inoculation, plants were potted in sterile soil $(1: 1: 1$, peat/soil/perlite) in separate plastic pots. At weekly intervals, representative plants were removed and the number, size, and total weight of galls were determined. All experiments were repeated at least twice. The reduction in the disease incidence was measured as a decrease in number and weight of tumors per plant. Uninoculated plants or plants inoculated solely with the pathogen were used as negative and positive controls of the severity of infection in the absence of biocontrol treatments. Wild-type strain K84 was used as a control of biocontrol efficiency.

Loss of biocontrol efficiency in transposon-induced mutants of strain K84 was screened in two steps. In the first, largescale screen, a single tomato plant was inoculated with a single mutant of K84 under conditions in which wild-type K84 yielded $100 \%$ biocontrol. Mutants of K84 inoculated to plants that formed galls after 5 weeks were considered to be compromised in biocontrol. Each of these potential biocontrol-deficient mutants was then screened a second time using 10 plants per mutant to quantify the extent of the biocontrol deficiency.

\section{Growth assays.}

Growth rates and final population yields in rich (MG/L) and minimal (ABM) liquid media were determined for strain K84 and each of its mutants. Cultures were adjusted to approximately $10^{3}$ viable cells per milliliter and were incubated at $26^{\circ} \mathrm{C}$ aerobically with shaking at $150 \mathrm{rpm}$ for up to 5 days. Viable cell counts were determined by plating decade dilutions on MG/L medium.

\section{Antibiotic production.}

Production of agrocin 84 was assayed on Stonier's medium plates (Stonier 1956) as previously described (Peñalver et al. 1994) using the sensitive strain C58 (Engler et al. 1975) as indicator. Production of ALS84 was assayed on MG medium plates as previously described (Peñalver et al. 1994) using strain NT1 as the sensitive indicator.

\section{Attachment and root colonization.}

Attachment to tomato seed and further colonization of roots were assayed in vitro in a gnotobiotic system. Tomato seed were surface sterilized for $10 \mathrm{~min}$ by soaking in hypochlorite (3.5\% [vol/vol] of active chloride, washed five times for $5 \mathrm{~min}$ in sterile water, and dried on sterile filter paper for $30 \mathrm{~min}$. Surface-sterilized seed were coated with bacteria by soaking for $30 \mathrm{~min}$ at $24^{\circ} \mathrm{C}$ with shaking at $150 \mathrm{rpm}$ in an inoculum of the bacterial culture adjusted to $\mathrm{OD}_{560}=0.8$ (approximately $\left.10^{9} \mathrm{CFU} / \mathrm{ml}\right)$ in $0.01 \mathrm{M}$ phosphate buffer saline (PBS) $(\mathrm{pH}=$ 7.2). Excess liquid was decanted and the seed were air dried for $10 \mathrm{~min}$ on sterile filter paper in a flow chamber. The number of bacteria attached to the seed was determined as follows. Bacteria were washed from four seeds per strain by vortexing for $10 \mathrm{~min}$ at room temperature in $1 \mathrm{ml}$ of $0.25 \times$ Ringer's solution (Schaad et al. 1990) containing 0.05\% Tween 20. Bacteria removed by this treatment were detected and quantified by spreading decade dilutions of the washing solutions on $\mathrm{MG} / \mathrm{L}$ plates. For evaluating root colonization, glass tubes $(15 \mathrm{~cm}$ high by $3 \mathrm{~cm}$ in diameter) were filled with $75 \mathrm{ml}$ of sterile soil (1:1:0.5, perlite/sand/peat) and moistened with $20 \mathrm{ml}$ of sterile PBS. Tomato seed coated with surface-adhering bacteria prepared as described above were sown at approximately $1 \mathrm{~cm}$ below the soil, and the plants were germinated and grown in a climatic chamber at $26^{\circ} \mathrm{C}$ with a daily photoperiodicity of $16 \mathrm{~h}$ of light and $8 \mathrm{~h}$ of darkness. At different times, 1-cm root pieces were excised from $1 \mathrm{~cm}$ above the root tip and the bacteria were washed off as described above from one root segment from four seedlings per mutant strain and quantified by dilution plating as described for the seed-attachment assays. All experiments were performed twice.

\section{Statistical analysis.}

Seed attachment and root tip colonization data were analyzed by a linear mixed model with strain as a fixed factor and experiment and its interaction as random. Because experiments and the interaction strain-experiment were not significant, these factors were removed from the model.

\section{ACKNOWLEDGMENTS}

We are grateful to S. Beck von Bodman and Z.-Q. Luo for technical advice and R. M. Farrand for technical assistance. We also thank J. M. Clark, Jr. and C. Roper for critical reading and text revision. R. Penyalver was the recipient of a postdoctoral fellowship from the Instituto Nacional de Investigaciones Agrarias (INIA) of Spain and also of a contract from the Ministerio de Educación y Ciencia (MEC) of Spain (Programa Ramón y Cajal). Portions of this work were supported by grant AG-95-01529 from the United States Department of Agriculture to S. K. Farrand and by grants RTA04-109 and RTA07-112 from INIA to R. Penyalver.

\section{LITURATURE CITED}

Abarca-Grau, A. M., Marco-Noales, E., Gámez, M. A., López M. M., and Penyalver, R. 2006. Biofilm production by Agrobacterium species on inert and plant surfaces. Page 111-112 in: Proc. 11th Int. Conf. Plant Pathogenic Bacteria (ICPPB). Edinburgh, Scotland, U.K.

Beringer, J. E., Beynon, J. L., Buchanan-Wollaston, A. V., and Johnston, A. W. B. 1978. Transfer of the drug-resistance transposon Tn5 to Rhizobium. Nature (Lond.) 276:633-634.

Bouzar, H., Daouzli, N., Krimi, Z., Alim, A., and Khemici, E. 1991. Crown gall incidence in plant nurseries of Algeria, characteristics of Agrobacterium tumefaciens strains, and biological control of strains sensitive and resistant to agrocin 84. Agronomie 11:901-908.

Cangelosi, G. A., Best, E. A., Martinetti, G., and Nester, E. W. 1992. Methods for genetic analysis of Agrobacterium. Methods Enzymol. 204:384-397

Cantoni, G. L., Richards, H. H., and Chiang, P. K. 1979. Inhibitors of 5adenosyl-homocysteine hydrolase and their role in the regulation of biological methylation. Page 155 in: Transmethylation. E. Usdin, R. T. Borchard, and C. R. Creveling, eds. Elsevier, Amsterdam.

Capela, D., Barloy-Hubler, F., Gouzy, J., Bothe, G., Ampe, F., Batut, J., Boistard, P., Becker, A., Boutry, M., Cadieu, E., Dréano, S., Gloux, S., Godrie, T., Goffeau, A., Kahn, D., Kiss, E., Lelaure, V., Masuy, D., Pohl, T., Portetelle, D., Pühler, A., Purnelle, B., Ramsperger, U., Renard, C., Thébault, P., Vandenbol, M., Weidner, S., and Galibert, F. 2001. Analysis of the chromosome sequence of the legume symbiont Sinorhizobium meliloti strain 1021. Proc. Natl. Acad. Sci. U.S.A. 98:9877-9882

Carter, R. A., Worsley, P. S., Sawers, G., Challis, G. L., Dilworth, M. J., Carson, K. C., Lawrence, J. A., Wexler, M. A., Johnston, W. B., and Yeoman, K. H. 2002. The $v b s$ genes that direct synthesis of the siderophore vicibactin in Rhizobium leguminosarum: Their expression in other genera requires ECF $\sigma$ factor RpoI. Mol. Microbiol. 44:11531166.

Chilton, M.-D., Currier, T. C., Farrand, S. K., Bendich, A. J., Gordon, M. P., and Nester, E. W. 1974. Agrobacterium tumefaciens DNA and PS8 bacteriophage DNA not detected in crown gall tumors. Proc. Natl. Acad. Sci. U.S.A. 71:3672-3676.

Chuang, D.-Y., Kyeremeh, A. G., Gunji, Y., Takahara, Y., Ehara, Y., and Kikumoto, T. 1999. Identification and cloning of an Erwinia carotovora subsp. carotovora bacteriocin regulator gene by insertional mutagenesis. J. Bacteriol. 181:1953-1957.

Cooksey, D. A., and Moore, L. W. 1980. Biological control of crown gall with fungal and bacterial antagonists. Phytopathology 70:506-509.

Cooksey, D. A., and Moore, L. W. 1982. Biological control of crown gall with an agrocin mutant of Agrobacterium radiobacter. Phytopathology 72:919-921.

Dong, Y. H., and Zhang, L. H. 2005. Quorum sensing and quorum-quenching enzymes. J. Microbiol. 43:101-109.

Donner, S. C., Jones, D. A., McClure, N. C., Rosewarne, G. M., Tate, M. E., Kerr, A. Fajardo, N. N., and Clare, B. G. 1993. Agrocin 434, a new 
plasmid encoded agrocin from the biocontrol Agrobacterium strains K84 and K1026, which inhibits biovar 2 agrobacteria. Physiol. Mol. Plant Pathol. 42:185-194.

Ellis, J. G., Kerr, A., van Montagu, M., and Schell, J. 1979. Agrobacterium: Genetic studies on agrocin 84 production and the biological control of crown gall. Physiol. Plant Pathol. 15:311-319.

Engler, G., Holsters, M., Van Montagu, M., Schell, J., Hernalsteens, J. P., and Schilperoort, R. 1975. Agrocin 84 sensitivity: A plasmid determined property in Agrobacterium tumefaciens. Mol. Gen. Genet. 138:345-349.

Farrand, S. K., and Wang, C. 1992. Do we really understand crown gall control by Agrobacterium radiobacter strain K84?. Pages 287-293 in: Biological Control of Plant Diseases. E. S. Tjamos and G. C. Papavizas eds. Plenum Press, New York.

Farrand, S. K., Slota, J. E., Shim, J. S., and Kerr, A. 1985. Tn5 insertion in the agrocin 84 plasmid: The conjugal nature of pAgK84 and the location of determinants for transfer and agrocin 84 production. Plasmid 13:106117.

Farrand, S. K., Hwang, I., and Cook, D. M. 1996. The tra region of the nopaline-type $\mathrm{Ti}$ plasmid is a chimera with elements related to the transfer systems of RS1010, RP4 and F. J. Bacteriol. 178:4233-4247.

Furuichi, T., Inouye, M., and Inouye, S. 1985. Novel one-step cloning vector with a transposable element: Application to the Myxococcus xanthus genome. J. Bacteriol. 164:270-275.

Galibert, F., Finan, T. M., Long, S. R., Puhler, A., Abola, P., Ampe, F., Barloy-Hubler, F., Barnett, M. J., Becker, A., Boistard, P., Bothe, G., Boutry, M., Bowser, L., Buhrmester, J., Cadieu, E., Capela, D., Chain, P., Cowie, A., Davis, R. W., Dreano, S., Federspiel, N. A., Fisher, R. F., Gloux, S., Godrie, T., Goffeau, A., Golding, B., Gouzy, J., Gurjal, M., Hernandez-Lucas, I., Hong, A., Huizar, L., Hyman, R. W., Jones, T., Kahn, D., Kahn, M. L., Kalman, S., Keating, D. H., Kiss, E., Komp, C., Lelaure, V., Masuy, D., Palm, C., Peck, M. C., Pohl, T. M., Portetelle, D., Purnelle, B., Ramsperger, U., Surzycki, R., Thebault, P., Vandenbol, M., Vorholter, F. J., Weidner, S., Wells, D. H., Wong, K., Yeh, K. C., and Batut, J. 2001. The composite genome of the legume symbiont Sinorhizobium meliloti. Science 293:668-672.

Glickmann, E., Gardan, L., Jacquet, S., Hussain, S., Elasri, M., Petit, A., and Dessaux, Y. 1998. Auxin production is a common feature of most pathovars of Pseudomonas syringae. Mol. Plant-Microbe Interact. 11:156-162.

González, V., Santamaría, R. I., Bustos, P, Hernández-González, I., Medrano-Soto, A., Moreno-Hagelsieb G., Janga, S. C., Ramírez, M. A., Jiménez-Jacinto, V., Collado-Vides, J., and Dávila, G. 2006. The partitioned Rhizobium etli genome: Genetic and metabolic redundancy in seven interacting replicons. Proc. Natl. Acad. Sci. U.S.A. 103:38343859.

Goodner, B., Hinkle, G., Gattung, S., Millar, N., Blanchard, M., Qurollo, B., Goldman, B.S., Cao, Y., Askenazi, M., Halling, C., Mullin, L., Houmiel, K., Gordon, J., Vaudin, M., Iartchouk, O., Epp, A., Liu, F., Wollam, C., Allinger, M., Doughty, D., Scout, C., Lappas, C., Markelz, B., Flanagan, C., Crowell, C., Gurson, J., Lomo, C., Sear, C., Strub, G., Cielo, C., and Slater, S. 2001. Genome sequence of the plant pathogen and biotechnology agent Agrobacterium tumefaciens C58. Science 294:2323-2328.

Hayman, G. T., and Farrand, S. K. 1988. Characterization and mapping of the agrocinopine-agrocin 84 locus on the nopaline Ti plasmid pTiC58. J. Bacteriol. 170:1759-1767.

Hayman, G. T., and Farrand, S. K. 1990. Agrobacterium plasmids encode structurally and functionally different loci for catabolism of agrocinopine-type opines. Mol. Gen. Genet. 223:465.

Johnson, K. B., and DiLeone, J. A. 1999. Effect of antibiosis on antagonist dose-plant disease response relationships for the biological control of crown gall of tomato and cherry. Phytopathology 89:974-980.

Jones, D. A., and Kerr, A. 1989. Agrobacterium radiobacter strain K1026, a genetically engineered derivative of strain $\mathrm{K} 84$, for biological control of crown gall. Plant Dis. 73:15-18.

Jones, D. A., Ryder, M. H., Clare, B. G., Farrand, S. K., and Kerr, A. 1988. Construction of a $\mathrm{Tra}^{-}$deletion mutant of pAgK84 to safeguard the biological control of crown gall. Mol. Gen. Genet. 212:207-214.

Kaneko, T., Nakamura, Y., Sato, S., Asamizu, E., Kato, T., Sasamoto, S., Watanabe, A., Idesawa, K., Ishikawa, A., Kawashima, K., Kimura, T., Kishida, Y., Kiyokawa, C., Kohara, M., Matsumoto, M., Matsuno, A., Mochizuki, Y., Nakayama, S., Nakazaki, N., Shimpo, S., Sugimoto, M., Takeuchi, C., Yamada, M., and Tabata S. 2000. Complete genome structure of the nitrogen-fixing symbiotic bacterium Mesorhizobium loti. DNA Res. 7:331-338.

Kerr, A. 1972. Biological control of crown gall: Seed inoculation. J. Appl Bacteriol. 35:493-497.

Kerr, A., and Htay, K. 1974. Biological control of crown gall through bacteriocin production. Physiol. Plant Pathol. 4:37-44.

Kim, J., Park, B. K., Kim, S., Choi, D., Nahm B. H., Moon, J. S., Reader,
J. S., Farrand, S. K., and Hwang, I. 2006. Bases of biocontrol: Sequence predicts synthesis and mode of action of agrocin 84, the Trojan Horse antibiotic that controls crown gall. Proc. Natl. Acad. Sci. U.S.A. 103:8846-8851.

Lippincott, B. B., and Lippincott, J. A. 1969. Bacterial attachment to a specific wound site as an essential stage in tumor initiation by Agrobacterium tumefaciens. J. Bacteriol. 97:620-628.

López, M. M., Gorris, M. T., Temprano, F. J., and Orive, R. J. 1987. Results of seven years of biological control of Agrobacterium tumefaciens in Spain. EPPO (Eur. Mediterr. Plant Prot. Organ.) Bull. 17:273-280.

López, M. M., Gorris, M. T., Salcedo, C. I., Montojo, A. M., and Miró, M. 1989. Evidence of biological control of Agrobacterium tumefaciens strains sensitive and resistant to agrocin 84 by different Agrobacterium radiobacter strains on stone fruit trees. Appl. Environ. Microbiol. 55:741-746.

McClure, N. C., Ahmadi, A. R., and Clare, B. G. 1998. Construction of a range of derivatives of the biological control strain Agrobacterium rhizogenes K84: A study of factors involved in biological control of crown gall disease. Appl. Environ. Microbiol. 64:3977-3982.

Moore, L. W., and Canfield, M. 1996. Biology of Agrobacterium and management of crown gall disease. Pages 151-191 in: Principles and Practice of Managing Soilborne Plant Pathogens. R. Hall, ed. American Phytopathological Society Press, St. Paul, MN, U.S.A.

Murphy, P. J., and Roberts, W. P. 1979. A basis for agrocin 84 sensitivity in Agrobacterium radiobacter. J. Gen. Microbiol. 114:207-213.

New, P. B., and Kerr, A. 1972. Biological control of crown gall: Field measurements and glasshouse experiments. J. Appl. Bacteriol. 35:279287.

Penyalver, R., and López, M. M. 1999. Co-colonization of the rhizosphere by pathogenic Agrobacterium strains and nonpathogenic strains K84 and K1026, used for crown gall biocontrol. Appl. Environ. Microbiol. 65:1936-1940.

Peñalver, R., Vicedo, B., Salcedo, C. I., and López, M. M. 1994. Agrobacterium radiobacter strain K84, K1026 and K84 Agr produce an antibiotic-like substance, active in vitro against $A$. tumefaciens and phytopathogenic Erwinia and Pseudomonas. Biocontrol Sci. Technol. 4:259-267.

Penyalver, R., Vicedo, B., and López, M. M. 2000. Use of the genetically engineered Agrobacterium strain K1026 for biological control of crown gall. Eur. J. Plant Pathol. 106:801-810

Penyalver, R., Oger, P., López, M. M., and Farrand, S. K. 2001. Iron-binding compounds from Agrobacterium spp:: Biological control strain Agrobacterium rhizogenes $\mathrm{K} 84$ produces a hydroxamate siderophore. Appl. Environ. Microbiol. 67:654-664.

Qin, Y., Luo, Z. Q., and Farrand, S. K. 2004. Domains formed within the $\mathrm{N}$-terminal region of the quorum-sensing activator TraR are required for transcriptional activation and direct interaction with RpoA from Agrobacterium. J. Biol. Chem. 279:40844-40851.

Reader, J. S., Ordoukhanian, P. T., Kim, J., Crécy-Lagard, V., Hwang, I., Farrand, S. K., and Schimmel, P. 2005. Major biocontrol of plant tumors targets tRNA synthetase. Science 309:1533.

Ryder, M. H., Slota, J. E., Scarim, A., and Farrand, S. K. 1987. Genetic analysis of agrocin 84 production and immunity in Agrobacterium spp. J. Bacteriol. 169:4184-4189.

Sambrook, J., Fritsch, E. F., and Maniatis, T. A. 1989. Molecular Cloning: A Laboratory Manual, 2nd ed. Cold Spring Harbor Laboratory, Cold Spring Harbor, NY, U.S.A.

Schaad, N. W., Sule, S., Van Vuurde, J. W. L., Uruggink, H., Alvarez, A. M., Benedict, A. A., De Wael, L., and Van Laere, O. 1990. Serology. Pages 153-190 in: Methods in Phytobacteriology. Z. Klement, K. Rudolph, and D. C. Sands, eds. Akademiai Kiado, Budapest, Hungary.

Sganga, M. W., Aksamit, R. R., Cantón, G. L., and Bauer, C. E. 1992. Mutational and nucleotide sequence analysis of $S$-adenosyl-L-homoysteine hydrolase from Rhodobacter capsulatus. Proc. Natl. Acad. Sci. U.S.A. 89:6328-6332.

Shim, J. S., Farrand, S. K., and Kerr, A. 1987. Biological control of crown gall: Construction and testing of new biocontrol agents. Phytopathology 77:463-466.

Simon, R. 1984. High frequency mobilization of gram-negative bacterial replicons by the in vitro constructed Tn5-mob transposón. Mol. Gen. Genet. 196:413-420.

Simon, R., Priefer, U., and Pühler, A. 1983. Vector plasmid for in vivo and in vitro manipulations of gram-negative bacteria. Pages 98-106 in: Molecular Genetics of the Bacteria-Plant Interaction. A. Pühler, ed. SpringVerlag KG, Berlin.

Stonier, T. 1956. Labelling crown gall bacteria with ${ }^{32} \mathrm{P}$ for radioautography. J. Bacteriol. 72:259-268.

Thomas, P. W., Stone, E. M., Costello, A. L., Tierney, D. L., and Fast, W 2005. The quorum-quenching lactonase from Bacillus thuringiensis is a metalloprotein. Biochemistry 44:7559-7569.

Uroz, S., Dessaux, Y., and Oger, P. 2009. Quorum sensing and quorum 
quenching: The yin and yang of bacterial communication. ChemBioChem.10:205-216.

Vicedo, B., Peñalver, R., Asíns, M. J., and López, M. M. 1993. Biological control of Agrobacterium tumefaciens, colonization, and pAgK84 transfer with Agrobacterium radiobacter K84 and the Tra mutant strain K1026. Appl. Environ. Microbiol. 59:309-315.

Wang, C.-L, Farrand, S. K., and Hwang, I. 1994. Organization and expression of the genes on pAgK84 that encode production of agrocin 84 Mol. Plant-Microbe Interact. 7:472-481.

Wood, D. W., Setubal, J. C., Kaul, R., Monks, D. E., Kitajima, J. P., Okura, V. K., Zhou, Y., Chen, L., Wood, G. E., Almeida, N. F., Jr., Woo, L., Chen, Y., Paulsen, I. T., Eisen, J. A., Karp, P. D., Bovee, D., Sr., Chapman, P., Clendenning, J., Deatherage, G., Gillet, W., Grant, C., Kutyavin, T., Levy, R., Li, M. J., McClelland, E., Palmieri, A., Raymond, C., Rouse, G., Saenphimmachak, C., Wu, Z., Romero, P., Gordon, D., Zhang, S., Yoo, H., Tao, Y., Biddle, P., Jung, M., Krespan, W., Perry, M., Gordon-Kamm, B., Liao, L., Kim, S., Hendrick, C., Zhao, Z. Y., Dolan, M., Chumley, F., Tingey, S. V., Tomb, J. F., Gordon, M. P., Olson, M. V., and Nester, E. W. 2001. The genome of the natural genetic engineer Agrobacterium tumefaciens C58. Science 294:23172323.

Young, J. P. W., Crossman, L. C., Johnston, A. W. B., Thomson, N. R.,
Ghazoui, Z. F., Hull, K. H., Wexler, M., Curson, A. R. J., Todd, J. D. Poole, P. S., Mauchline, T. H., East, A. K., Quail, M. A., Churcher, C., Arrowsmith, C., Cherevach, I., Chillingworth, T., Clarke, K., Cronin, A., Davis, P., Fraser, A., Hance, Z., Hauser, H., Jagels, K., Moule, S. Mungall, K., Norbertczak, H., Rabbinowitsch, E., Sanders, M., Simmonds, M., Whitehead, S., and Parkhill, J. 2006. The genome of Rhizobium leguminosarum has recognizable core and accessory components. Genome Biol. 7:Art. No. R34.

\section{AUTHOR-RECOMMENDED INTERNET RESOURCES}

Baylor College of Medicine Search Launcher: searchlauncher.bcm.tmc.edu/multi-align/multi-align.html

INRA Sinorhizobium meliloti 1021 webpage: sequence.toulouse.inra.fr/meliloti.htm

National Center for Biotechnology Information website: www.ncbi.nlm.nih.gov

RhizoBase: genome.kazusa.or.jp/rhizobase

University of Washington Crown Gall Group: depts.washington.edu/agro Virginia Tech Bioinformatics Institute Genome sequencing webpage: agro.vbi.vt.edu/public/index.html 